\title{
ON THE REFERENTIAL INTERPRETATION OF COMPUTER-MEDIATED NARRATIVES
}

\author{
Krisztina Laczkó and Szilárd Tátrai \\ Eötvös Loránd University
}

\begin{abstract}
The paper explores the referential interpretation of narratives through a case study of computer-mediated narrative discourse, a thread of Hungarian stories on an online discussion site. In particular, we are looking to find out what directs the addressee's attention and how as she attempts to interpret such stories. Adopting the perspective of social cognitive linguistics, we interpret narrative discourses as joint attentional scenes whose interacting participants contribute to the intersubjective construal of referential scenes (including narrative ones) by directing and following each other's attention. The main results of the investigation are as follows. 1) In the construal of the physical and social worlds of these stories, a key role is played by the deictic relation based on spatial and temporal contiguity which connects the world of the story to the world of the narrative discourse, interpreted as a joint attentional scene. 2) These narrative discourses frequently objectivize, in the form of metapragmatic reflections, both the situatedness of the referential centre (which lies with the storyteller), and the narrator's subjective attitude to the narrated events.
\end{abstract}

Keywords: joint attentional scenes, narratives, social cognitive linguistics, deixis, Hungarian

DOI: http://dx.doi.org/10.12697/jeful.2015.6.2.04

\section{Introduction}

In this paper, we approach the referential interpretation of computermediated conversational narratives from the perspective of the contextdependent directing of attention. The first part of the study lays out the theoretical assumptions behind the investigations. From a social cognitive linguistic perspective, we interpret narrative discourses as scenes of joint attention, and stories as referential scenes. We will be especially concerned with the functioning of the referential centre, as well as the deictic relation between the scene of joint attention and the referential scene, based on their spatial and temporal contiguity. Moreover, we will pay special attention to the phenomenon of metapragmatic awareness, 
i.e. the discourse partners' reflexive attitudes to their own linguistic activity. In the second part, this will be followed by the findings of our corpus study on the most characteristic genre-specific features of narrative discourse, namely (i) reflections on the situatedness of narration, (ii) reflections on the physical and social worlds of narration, and (iii) construal of the stories' physical and social worlds. Throughout the paper, we will focus on the most typical linguistic instantiations.

\section{Theoretical assumptions}

The meaningful functioning of language includes several discourse types commonly referred to as "narrative" whose defining feature is that their discourse participants construe and share their experiences of the world in (and through) stories (see Tátrai 2015, cf. Bruner 1986, Tomasello 1999: 161-200). In this paper, we address the question of how computer-mediated narratives receive a referential interpretation by exploring the organization and functioning of contextdependent vantage points. Our key concern will be to examine (i) what is directing our attention and how it does so during the processing of narratives, and (ii) how particular modes of directing attention invite particular modes of conceptualization. The functional cognitive (and more specifically, social cognitive, cf. Croft 2009) perspective applied in this paper is strongly related to constructivist and post-structuralist approaches to narratives "which [see] stories as selective (re)playings and (re)constructions rather than as accurate reflections and representations of events. As such, their tellings are shifting, dynamic, and contextually grounded, rather than given and pre-determined. They are produced as part of social interactions in specific situations and for specific purposes" (Georgakopoulou 2011: 193).

Dynamic meaning generation occurs in a discourse which unfolds as a joint attentional scene (cf. Tomasello 1999, Sinha 2005, Tátrai 2011). Joint attentional scenes feature the interaction of discourse participants (speakers and hearers) employing a natural language (or languages), directing and following each other's attention, and intersubjectively ${ }^{1}$

1 We interpret the notion of intersubjectivity as a special feature of the employment of linguistic symbols, closely related to referentiality. It concerns our ability to regard fellow humans as intentional and mental agents similar to ourselves, who (just like us) are capable of directing their discourse partners' attention to objects and events in the world in the framework of a triadic system of relations (see Tátrai 2011: 29-35, cf. Tomasello 1999, Verhagen 2007). 
construing a referential scene as dictated by the adaptive satisfaction of their communicative needs (cf. Verschueren 1999). This means that establishing a joint attentional scene is a pre-requisite for symbolic linguistic communication. It is an intersubjective act allowing us to draw another person's attention to the objects and events of the world (to the referential scene), thereby influencing her mental orientation (attention as well as interpretation). The observation and interpretation of a referential scene occurs in a discourse universe, which includes:

a) the joint attentional scene along with the discourse participants and their physical, social and mental worlds, which they are processing jointly over the course of their interaction,

b) the linguistic symbols being employed, and hence placed into an intersubjective context, within the joint attentional scene, and

c) the referential scene whose observation and interpretation these linguistic symbols afford; in other words, the participants' experience of the world as it is linguistically construed and shared with others.

This deserves special emphasis because the interpretive model of narratives to be outlined below also puts a premium on the intersubjective and also perspectival nature of linguistic symbols (see Tomasello 1999: 128). Linguistic symbols open the way for alternate construals of our experience of the world (cf. Verhagen 2007, Langacker 2008: 55-89). On the one hand, they code varying conceptualizations; on the other, they also prompt for variation in conceptual processing (cf. Sinha 1999). The perspectival nature of linguistic symbols is exploited in discourse by the adoption of a speaker's context-dependent vantage point. Naturally, this also holds true for narratives.

Up to this point, we have been concerned with the general discursive character of narrative discourses, therefore it is time to address their specific narrative character as well. Narrative understanding - based on declarative knowledge - demands a special interpretive attitude from us as addressees (hearers, readers) because we need to comprehend a story in the referential scene, a story which allows us to follow the agents in space and time, and to discover temporal and causal relations among situations and events (cf. Tomasello 1999: 172-210, Brown 1994). In addition, it deserves special mention that narrative discourses typically call on discourse participants to draw their attention to a referential scene (a series of events) which does not bear a direct (perceptual) rela- 
tion to the physical world of the speech event. This necessarily demands a more indirect mode of conceptual processing.

The referential interpretation of linguistic symbols employed in a narrative discourse, that is, its epistemic grounding in the intersubjective context of the joint attentional scene, is closely related to orientation in the discourse universe, which in turn depends on the functioning of the storyteller's vantage point. Therefore, the interpretation of referential scenes in narrative discourses is crucially affected by which discourse participant is directing construal operations, who decides from where and how the referential scene (a series of narrated events) should be presented (see Tátrai 2011: 171-189, 2015). Thus, the basic questions are the following:

a) How is the conceptually processed physical world of the story being construed, along with its spatial and temporal relations?

b) How is the conceptually processed social world of the story being construed, along with its interpersonal relations?

c) How is the mental world of the story's characters being construed, including such mental states as their intentions, desires, beliefs and emotions?

In this paper, we focus on how the physical and social worlds of the story are construed. In this regard, a key role is played by the referential centre, which serves as a context-dependent vantage point (cf. SandersSpooren 1997, Tátrai 2008). The referential centre marks the point of orientation from which the spatial, temporal and interpersonal relations of the referential scene are to be construed. By default, this centre lies with the speaker and her position in space and time, as determined by the embodied grounding of linguistic cognition. Therefore, the referential centre is a context-dependent vantage point associated with the discourse participant functioning as speaker. However, the discursive grounding of linguistic cognition also provides for opportunities to shift this centre of orientation (partially or completely) onto another entity, especially another person, for example some other agent within the story.

A further important point about the computer-mediated narrative utterances under study is that the functioning of the referential centre is crucially affected by the construed deictic relation between the world of the story (the narrated events) and the world of the storytelling (the speech event). The basis of this deictic relation is spatio-temporal contiguity between the physical world of the story and that of the narra- 
tive discourse (cf. Tátrai 2008, 2015). Put simply, the narrated events are assumed to occur in the same reality that the storytellers and their addressees inhabit, and in which their discourse unfolds. This relation is further reinforced when the storytellers are telling stories in which they themselves also participated. In such cases, it becomes evident that the social world of the story is also closely linked to that of the speech event, since one participant of the story is being construed as a former self of the storyteller. This means that the storyteller has a profiled and stable centre of orientation, defined relative to the narrated events, from which to access and interpret the story's spatio-temporal and social relations. However, this of course does not preclude the possibility of the storyteller shifting the referential centre for spatial, temporal and interpersonal orientation onto another character. Rather, the point is that any partial or complete shifting of the referential centre must occur relative to a narrator as a context-dependent centre of orientation.

\section{Material and method}

Our corpus was supplied by the internet-mediated genre of thematic threads, more specifically a discourse focusing on storytelling. With regard to spatio-temporal relations and participant roles, it is important to highlight that the speakers and addressees are never in the same physical space, and successful communication does not require simultaneity, as the utterances are archived to be retrieved and processed at any time. The speakers participate anonymously in the discourse, and for the most part they do not know each other, thus their mutual perceptions are driven primarily by each other's linguistic performance. This means that the internet-mediated narratives under study are distinguished by their mediality from prototypical conversational narrative discourses occurring in face-to-face spoken interactions. However, their other features including spontaneity, dialogicity and the corresponding reliance on schemas typical of conversational narratives still bring them closer to the prototype of conversational rather than literary narratives (cf. Tátrai 2011: 74-80; 2015).

The thread we used as a corpus is titled Beégésem története 'The story of my embarrassment'. It is available on the message board of one of the most popular Hungarian web portals, Index ${ }^{2}$. Naturally, it consists

2 http://forum.index.hu/Article/showArticle?t=9017476\&la=125481821 
exclusively of Hungarian utterances. The thread starter describes the goals of the thread in the first post as follows.

(1) Széleskörü tapasztalat, hogy személytelenül az ember sokkal könnyebben beszél számára kellemetlen dolgokról is, sokkal hajlamosabb az öniróniára. Nos, ez a témakör igazolhatja a fenti véleményt. Arra kérek ugyanis minden ide látogatót, osszátok meg a többiekkel életetek legnagyobb leégéseinek történetét, amikor tényleg ott álltatok megszégyenülve, és mindenki rajtatok röhögött. Minél nagyobb az égés, annál jobb a sztori!

'It is a widely shared experience that people are more at ease talking about unpleasant things affecting them, and more prone to self-irony when they enjoy anonymity. Well, this thread may verify this claim. I call on all visitors to share the stories of your biggest embarrassments, when you were just standing there humiliated, and everyone was laughing at you. The bigger the embarrassment, the better the story!'

The discourse started in May 2000, and contains 26,019 posts at present. In keeping with the thread starter's request, $83.6 \%$ of posts are narratives, complemented in a discursive way by reactions to the stories and other posts, occasionally off-topic conversations. For the purposes of this study, we selected 100 narratives and saved them in a separate file in chronological order (numbered). The stories contain 130 word tokens on average, the shortest being 36, the longest 393 words long. Our generalizations will be based on the most typical features of text construal and will spell out the key findings of a more detailed investigation. At this stage, the research is qualitative in nature, as the material has not been subjected to statistical analysis.

\section{Results}

\subsection{Metapragmatic awareness}

A key feature of the narratives under study is that numerous genrespecific references are made to the speech event itself. In other words, the linguistic activity of the speaker becomes the object of metapragmatic awareness (cf. Verschueren 1999: 187-198, Tátrai 2011: 119-125), as a special and salient feature of internet-mediated narrative discourse.

The notion of metapragmatic awareness concerns the self-conscious reflection of discourse participants on the linguistic activity and their dynamic meaning generation within it. Speakers may reflect on them- 
selves, the addressees, or third parties (regarding their roles and activities), or else on the ongoing discourse and its organization. This entails that participants are able to reflect on the variability of linguistic representations and corresponding social cognitive processes as well as sociocultural expectations. Metapragmatic awareness has observable linguistic footprints called metapragmatic markers. The level of semantic elaboration of these markers correlates iconically with the speaker's degree of metapragmatic awareness. However, metapragmatic awareness cannot be equated with the employment of metapragmatic markers by the speaker; rather, it is a global feature of discourse hinging on the participants' attitude to their shared linguistic activity and dynamic meaning generation.

In our corpus of computer-mediated narratives, there is clear evidence of a high degree of metapragmatic awareness. Speakers make liberal use of metapragmatic markers, with only 16 texts (out of 100) lacking such devices. The remaining 84 thread posts include reflections of varying degrees of elaboration and explicitness on the narrative situation.

\subsubsection{Characteristic types of metapragmatic reflection}

Three types of metapragmatic reflection can be discerned in the corpus: A) reflection on the storytelling, B) reflection on the addressee's activity, and C) reflection on the organization of the discourse. These are not independent of each other, but rather interrelated in specific ways, depending on whether the focus of reflection is on the linguistic activity of the discourse participants, on the construal of the referential scene, or on the referential scene itself. ${ }^{3}$

A) Reflection on the storytelling is most conspicuously marked by first person singular verbs and their constructions, e.g. elmondok még egyet 'I'll tell another one'; megpróbálom szavakkal visszaadni 'I'll try putting it into words'; megosztom pár beégésem 'I'll share some of my embarrassments'; irogatok ide történetet 'I'm scribbling down a story

3 In this paper, we focus on types of reflection rather than giving an account of the linguistic markers of metapragmatic awareness. Our aim is also to highlight the fact that metapragmatic awareness cannot be put down to the employment of linguistic markers by the speaker. Rather, it concerns the varying degrees of reflective attitude that speakers and hearers alike bring to bear on their shared linguistic activity and dynamic meaning generation. 
here'; saját történettel hozakodnék elö 'I'd like to bring a personal story here'; idemásolom a sztorit 'I'll copy the story here'; elöhozakodok eggyel 'I'll bring one here'; riogatlak titeket a történetemmel 'I'm scaring you with my story'; remélem, még nem mondtam el nektek, régen szóltam hozzá, gazdagitom a fórumot 'I hope I haven't told you this before, I haven't been here for long, I am enriching this thread'. In the latter case, the addressee's mental activity is profiled, construed with cognitive verbs.

A specific form of reflecting on the storyteller's activity is the marking of who or where the story is coming from: egy ismerösöm/ kolléganöm mesélte 'my acquaintance/colleague told me'; a történet a rádióban is elhangzott 'this story was also featured on the radio'; haverok mesélték a következö sztorit 'my pals told me the following story'; erröl eszembe jutott 'this has reminded me of'; láttam, olvastam valahol 'I saw/read it somewhere'; hallottam a sztorit 'I've heard the story'. This may be regarded as a type of quotation in which the speaker is reflecting on the re-telling of the story and thus also on the narrative activity of someone else. The relatively high frequency and prominence of this phenomenon in our corpus can be explained by the fact that the thread invites contributors to share their own experiences, as already expressed by the title. Failure to comply with these expectations needs to be explicitly marked, which translates into high levels of reflection on the re-telling of other people's stories in the corpus.

B) Reflections on the addressee's activity of text comprehension are predominantly expressed by verbs in the second person plural: tudjátok 'you know'; ti akartátok... 'you wanted this'; megosztom veled és mindenkivel, aki olvassa 'I am sharing this with you and with everybody reading this'; na ezt figyeljétek 'hey, listen to this'; na akkor kapaszkodjatok 'now hold yourselves tight'; talán emlékeztek 'maybe you remember'; ezt add össze 'add this up'; titeket riogatlak a történettel 'I'm scaring you with the story'; Emberek! 'People!'; riogatlak titeket 'I'm scaring you'; nem meséltem még nektek 'I haven't told you about this'; hát ezt fogjátok meg 'now get this'. In this group, the addressee's (i.e. the discourse partner's) mental activity is profiled, construed with cognitive verbs. 
C) Reflections on one's concurrent or a previous narrative utterance ${ }^{4}$ are typically construed in a conceptually elaborate manner: $e z a$ történet 'this story', az én sztorim 'my story', a következö eset 'the next case', ez csak izelitö 'this is only an appetizer', az elsö epizód 'the first episode', or with a more topical construal: ez a beégés 'this humiliation'. Constructs with the demonstrative pronoun $e z$ 'this' are similarly frequent:

(2) Ezt [this-ACC] nehéz lesz szavakban visszaadni, de megpróbálom... 'It is difficult to put this into words, but I'll try...'

(3) Egy ismerősöm mesélte ezt [this-ACC]:

'An acquaintance of mine told me this'

(4) $E z$ [this-NOM] nem olyan égés, csak állandóan ciki helyzetbe hoz:

'This is not so much about embarrassing myself but it always puts me into an awkward situation:'

In Hungarian, the pronoun $e z$ 'this' is the most typical discourseorganizing element. This is demonstrated by $(2-4)$ as well, in which the pronoun performs discourse deixis ${ }^{5}$ by referring cataphorically to the upcoming story (with a quotation-like construal in (3)).

Metapragmatic markers include various discourse markers as well (Frazer 1999), which also express reflections on discourse organization, dividing the discourse into sequences and connecting the segments, thus playing an important part in the directing of attention: nos 'well', na 'so', namost 'now then', szóval 'well', hát 'well', ugye 'you know'.

4 From a functional cognitive perspective, we regard utterances from a processingbased standpoint as an act of directing attention whereby one discourse participant (the speaker or writer) uses her context-dependent vantage point to influence the other participant's mental orientation (attention, understanding) in a discourse universe. From a structural point of view, utterances are interpreted as units subserving the directing of attention, whose length and complexity may vary considerably (Tátrai 2011: 68-74, cf. Verschueren 1999: 113-146).

5 Discourse deixis pertains to linguistic operations with the purpose of pointing at the discourse as a whole or some parts thereof. It is a special type of deixis because unlike spatial, temporal and social deixis, it does not bring situative factors into play in interpretation but rather construes the discourse itself and its organization as objects of reflection (Tátrai 2011: 142-144). 


\subsubsection{The distribution of metapragmatic markers}

The distribution of metapragmatic reflections vis-à-vis the narrative storyline reveals a characteristic pattern. They are predominantly found at the beginning of the storytelling, with only 5 out of 84 relevant utterances lacking initial metapragmatic markers. The markers in this position typically pertain to the narrative utterance, often accompanied by (rather elliptical) reference to the storytelling activity. Consider the following examples.
$\mathrm{Az}$ én
egyik nagy égésem:
the 1sG.NOM one of big humiliation.1sG.GEN
'One of my big humiliations:'

$\begin{array}{lll}\text { (6) } \mathrm{Na} & \text { még } & \text { egyet: } \\ \text { so } & \text { another } & \text { one.ACC }\end{array}$

'So another one:'

In these (relatively rare) cases, there is no proximal demonstrative pronoun which would contribute to the construal of metapragmatic reflection. In writing, however, the punctuation mark of the colon appropriately takes over its role. By contrast, metapragmatic markers rarely occur in closing position (only 18 times). Here, the speaker is referring back to her previous discourse or forward to a possible followup, or else the closing of the narrative utterance is being profiled.

(7) Remélem, belefér ilyen [this kind of-ADJ] is a témába. 'I hope this kind of stuff also fits into this topic.'

(8) Közben eszembe jutott egy újabb sztori [one new-comp story-nom], csak dolgoznom is kéne, úgyhogy majd kicsit később.

'Meanwhile another story has come to mind, but I have work to do, so a little later.'

(9) A tanulságot mindenki vonja le magának! the lesson.ACC everybody 3sG.draw.IMP down.PREFIX REFL.3SG.DAT 'Everybody draw the lesson for themselves!'

(10) $\mathrm{Na}$ ennyit erröl. Majd ha még eszembe jut, mondok. so this much.ACC this.ABL

'That's all about this. When I remember more, I'll tell them.' 
There the running text also features a high number of metapragmatic markers; around $80 \%$ of these, however, have a schematic semantic structure.

(11) A doktornő a legkisebb betegségre is vagy háromféle gyógyszert felírt.

Nomármost [so already now], az én influenzámra is kaptunk egy csomót.

'The doctor prescribed around three different pills even for the mildest disease. Now then, we also got a whole bunch for my flu.'

Among other types of metapragmatic reflections, pronominal discourse deictic elements reflecting on particular parts of the referential scene occur regularly, e.g.:

(12) $E z$ [this-NOM] később még fontos lesz.

'This will be important later.'

Reflection on the storytelling activity does not appear in the middle of the text. However, reflections on the text's reception by the addressee do occur in a limited number, sometimes in a semantically elaborate manner, as in (14), or elliptically, as in (15).

(13) Rögtön hívja a hölgyet, akihez jött, erre kitalálhatjátok [guess-POTENT2PL], ki lépett ki az ajtón.

'He calls the lady immediately, the one he has come to, and then you can guess who was stepping out of the door.'

(14) Logikus, nem?

'Logical, isn't it?'

The likely reason for the distribution pattern of metapragmatic markers is that, even though the thematic nature of the topic thread and the arrangement of written text on the screen would not require marking the beginning and end of the storytelling, the conventional schemas of the genre and the speaker's intention to use signals for the directing of attention result in a high level of reflection on the narrative situation.

Generally speaking, these narrative utterances are characterized by the fact that the storyteller foregrounds herself, making explicit the context-dependent vantage points of her narrative utterance by means of metapragmatic reflection. Hence, a prominent role is played by both the 'here and now' of referential orientation (anchored to the storyteller) and the narrator's subjective attitude to the narrated events. 


\subsection{The physical and social worlds of narration}

The physical and social worlds of the story are closely intertwined, which is best reflected in the dual grounding of characters (cf. Tátrai 2015). On the one hand, they form part of the (conceptually construed) physical world of the story which provides time and space for their goal-oriented actions as well as anything that happens to them. On the other, these characters are not simply physical entities appearing in the time and space of the story; rather, they are also involved in a network of social relations. How they establish and manage these social relations also needs to be construed by the storyteller, just as spatial and temporal relations do.

\subsubsection{The physical world of stories}

The physical world of a story results from processing the spatial and temporal relations of the narrated events, in which certain agents perform certain actions to achieve certain goals. When the physical world of the story is being construed, the referential centre for spatial orientation is often shifted to the space and time of the story. ${ }^{6}$

(15) Kollégista vagyok itt [here] Budapesten, amíg még tart a vizsgaidőszak. 'I'm a dorm student here in Budapest until the end of the exam period.'

(16) A lány a pillanat törtrésze alatt felugrott az ágyról, merthogy a mama már itt [here] is volt...

'The girl jumped up from the bed in a fraction of the second as her mum was already here.'

(17) A boltos meg csak integet, hogy tünjünk el innen [here-ABL].

'And the shop owner is just waving to us that we get the hell out of here.'

In (16), itt 'here' refers to the speaker's physical world, which plays a relevant role in the story. By contrast, itt 'here' and innen 'from here,

6 The shifting of the referential centre is also known as deictic projection (Lyons 1977: 579, see Fillmore 1975), which may pertain to orientation in spatial, temporal and interpersonal dimensions alike. The employment of vantage points distinct from the speaker's is made possible by the fact that humans engaged in linguistic activity (as a function of the social cognitive nature of this activity) are able to put themselves in someone else's place, in other words to assume other people's perspectives (Tomasello 1999). 
out of here' in (17) and (18) are deictic projections, that is, they mark the shifting of the origo (the referential centre) from the given speaker's location to the given character's location. What is more, this occurs in (17) despite the fact that the narrator did not play an active role in the story.

(18) Ám most [now] mégsem kellett neki a sült tök, ezért amikor kilépett a liftből, fennhangon a lányhoz szólt.

'Yet now he didn't need the fried pumpkin after all, so when he stepped out of the elevator, he addressed the girl with a loud voice.'

(19) Már teljesen kipilledve vánszorgunk a 4-6-os villamos egyik megállójában (azt ismertük!!), de ötletünk se volt, most akkor [now then] merre.

'Worn out completely, we are trudging around the stop of trams number 4 and 6 (that's the only place we knew!!) but we had no idea now then where to go.'

(20) Na most [so now], közös ismeröseink révén én ezzel a lánnyal köszönőviszonyban voltam.

'So now, thanks to our shared acquaintances, I was in a nodding relationship with this girl.'

(21) Namost [so now], egyszer az állatkertet megfejeltük egy vidámparkkal is. 'So now, on one occasion, in addition to the zoo we also went to the amusement park.'

The use of most 'now' in (18) and (19) exemplifies the shifting of the referential centre for temporal orientation in a story narrated in past tense. In (20) and (21), however, the forms most 'now', na most 'so now, now then' function as metapragmatic markers, discourse deictic elements. Finally, (22) and (23) demonstrate that most 'now' and most is 'still' typically appear in metapragmatic reflections when they refer to the time of the storytelling.

(22) Majd lesz még történet, de most [now] nem jut eszembe.

'I will have more stories but now I can't remember any.'

(23) Még most is [now too] iszonyúan szégyellem ezt az egészet.

'I am still terribly ashamed of this whole thing.' 
The employment of present tense forms for relating past events, as illustrated by (24-26), also amounts to a shifting of the referential centre of temporal orientation onto the characters of the referential scene.

(24) Barátnőmmel bemegyünk [in-go-PRs-1PL] egy telefonfülkébe. Találunk [find-PRs-1PL]egy táskát. Kinyitjuk, mi az? [out-open-PRs-1PL, what that] Egy pisztoly.

'We are going into a phone booth with my girlfriend. We find a bag. We open it, and what is it? A pistol.'

(25) Erre másnap elkap [prf-catch-PRs-3sG] engem is a nő, hogy gratulál, milyen ügyes voltam, stb., mondom [say-pRs-1sG], köszönöm, igen.

'Then the following day I'm also caught by the woman, she congratulates me on how clever I was, etc., I'm saying, thank you, yes.'

(26) Kirándulás, lelkes amatör fotózik [photo-DERIV-PRs-3sG]: valamelyik barát barátja, elkészülnek [PRF-ready-DERIV-PRS-3PL] a képek, a társaság összejön [together-come-PRS-3sG] megcsodálni őket, jókat röhögünk [laugh-PRS-1PL], milyen idétlen fotókat sikerült rólam készíteni, lelkes amatör közli [declare-3sG], hogy rossz a fotóarcom, nem szólok [say-1sG] semmit, habár nem vagyok szépség.

'Excursion, amateur enthusiast taking pictures: he's a friend of a friend, the pictures are done, everybody's coming together to have a look, we're having a great laugh at the silly pics taken of me, then the amateur enthusiast declares that my face is not photogenic, I don't say anything, even though I'm not a beauty.'

Based on our corpus data, the referential centre for construing the physical space of the story is most commonly achieved by the use of praesens historicum. It occurs in $80 \%$ of the narratives, usually interspersed with past tense forms.

\subsubsection{The social world of the story}

The referential interpretation of the story also involves construing its social world. In this respect, a decisive factor is whether the narrator is telling a story in which he himself also actively participated. In I-narratives, the functioning of context-dependent vantage points is fundamentally influenced by the deictic relation between the speech event and the narrated events. The storyteller, functioning as a context-dependent reference point, construes other characters with respect to herself, the 
most obvious manifestation of which is the use of first person possessive suffixes especially when a new character is introduced, cf. osztálytársunk 'classmate-Poss(1PL)' / 'our classmate', barátom 'friend-Poss(1 $1 \mathrm{sG})$ ' / 'my friend', fönököm 'boss-poss(1sG)', szüleim 'parents-Poss(1sG)' / 'my parents', századosunk 'captain-Poss(1PL)' / 'our captain'.

Similarly to what holds true for the construal of the physical world, the referential centre for interpersonal orientation may also be shifted onto someone else, but this is much rarer. A case in point is when the narrator is presenting herself in the third person singular, also construing her social relations from this vantage point. The corpus contains three stories with this feature:

a. Általános 4. osztály. Gini új iskolába megy [go-PRs-3sG]. Jólértesült Gini lehuppan [down-plunk-PRs-3sG] egy szőke lány mellé és barátkozik [friend-DERIV-PRS-3SG] ezerrel. [...] Azt hiszem, ezen a ponton szoktam le [give-PST-1sg down] a pletykálásról végérvényesen.

'Primary school, 4th form. Gini is moving to a new school. Wellinformed Gini plunks herself down next to a blond girl and is busy making friends. [...] I think it is at this point that I quit gossiping for good.'

b. A fiatal 17 éves srácnak [boy-DAT] nagyon tetszik [like-PRS-3sG] egy lány, barátkoznak [friend-DERIV-PRS-3PL], találkozgatnak [meet-FREQ-PRS-3PL] (de nem történik semmi). A srác egy napon felhivja [call-PRs-3sg up], randiügyben, Gabi (lány) azt javasolja, a srác menjen el hozzá aznap délután, mert nincsenek otthon a szülők, pár napra elutaztak a telekre és csak este jönnek haza. [...] Én egy kicsit még vártam [wait-PST-1sG] Gabira, aki nem jött, aztán a világ egyik legnagyobb leégésének tudatával elléptem [off-step-PST-1SG]...

'The young 17-year-old guy really fancies a girl, they are making friends, dating (but nothing is happening). One day the guy calls her, about a date, then Gabi (the girl) suggests he should visit her in the afternoon as the parents are away, they are off to the countryside and aren't coming back until the evening. [...] For a while I kept waiting for Gabi, who wasn't coming, then I left with a sense of one of the biggest embarrassments the world has seen...'

c. Matyika is nyargalt [gallop-PST-3sG] lefele a tornaöltözöbe, de látja [see-PST-3SG] ám, hogy az osztályteremben a csapattársai egy pad fölé görnyedve iszonyatosan bifláznak valamit. [...] Hát jól lebuktam [PRFdive-PST-1sG] :) 
'Matyika was also galloping down to the dressing room, until he notices that in the classroom, his teammates are bent over a table, cramming like hell. [...] Well, I got busted all right. :)

All three examples are characterized by the fact that the narrator shifts into first person singular at the end of the story. This produces a strong stylistic effect, finally making it completely clear that the story has in fact been an I-narrative.

\section{Summary}

In the referential interpretation of computer-mediated conversational narrative utterances, the following general devices of construal have been found salient:

- The act of storytelling often becomes the object of metapragmatic reflections. We described each subtype in detail on the basis of their degrees of semantic elaboration and also attempted to reveal distribution patterns of markers of reflection with respect to the story.

- Elaborate reflections on the storyteller's linguistic activity and the recipient's mental processing occur most often at the beginning of stories. In the middle of the story, discourse markers dominate before the narrator's reflections return towards the end, but this time in smaller numbers and in a semantically less elaborate manner.

- Discourse deictic demonstrative pronouns are found in every position, but they are significantly more frequent at the beginning than $t$ the end. In these two positions, they mark reflections on the referential scene as a whole, while in the running text they only have scope over some part of the referential scene.

- In the construal of the physical and social worlds of these stories, a key role is played by the deictic relation based on spatio-temporal contiguity which connects the world of the story to the world of the narrative discourse, interpreted as a joint attentional scene.

- In the construal of the stories' physical worlds, the referential centre for spatial and temporal orientation is relatively frequently shifted onto characters of the story.

- However, in the construal of the stories' social worlds, the referential centre for interpersonal orientation is only rarely shifted onto characters of the story. 
These remarks highlight genre-specific features. Therefore, it will be important to learn how spontaneous spoken narratives compare to our findings on computer-mediated discourse and to determine the extent to which conventional features of spoken dialogues appear in online conversations.

\title{
Acknowledgements
}

This paper was supported by grant K 100717 of OTKA (Hungarian Scientific Research Fund).

\author{
Addresses: \\ Krisztina Laczkó \\ Eötvös Loránd University \\ Faculty of Art \\ H-1088 Budapest \\ Múzeum krt. 4/A \\ E-mail: laczko.krisztina@illetve.hu \\ Szilárd Tátrai \\ Eötvös Loránd University \\ Faculty of Art \\ H-1088 Budapest \\ Múzeum krt. 4/A \\ E-mail: tatrai.szilard@gmail.com
}

\begin{abstract}
Abbreviations
In the glossings appear the following abbreviations not included in Leipzig glossing rules: DERIV - derivational suffix, FREQ - frequentative, POTENT - potential.
\end{abstract}

\section{References}

Brown, Gillian (1994) “Modes of understanding”. In Gillian Brown, Kirsten Malmkjaer, Alaistair Pollitt, and John Williams, eds. Language and understanding, 10-20. Oxford: Oxford University Press.

Bruner, Jerome (1986) Actual minds, possible words. Cambridge MA: Harvard University Press. 
Croft, William (2009) Towards a social cognitive linguistics. In Vyvyan Evans and Stephanie Poursel eds. New directions in cognitive linguistics, 395-420. Amsterdam: John Benjamins.

Fillmore, Charles J. (1975) Santa Cruz lectures on deixis. Indiana University Linguistics Club.

Frazer, Bruce (1999) "What are discourse markers?" Journal of Pragmatics 31, 931-952.

Georgakopoulou, Alexandra (2011) "Narrative". In Jan Zienkowski, Jan-Ola Östman, and Jef Verschueren, eds. Discoursive Pragmatics, 190-207. (Handbook of Pragmatics Highlights, 8.) Amsterdam and Philadelphia: John Benjamins.

Laczkó, Krisztina and Szilárd Tátrai (2012) "Személyek és/vagy dolgok. A harmadik személyü és a mutató névmási deixis a magyarban.” [Persons and/or things. Third person and demonstrative pronouns as deictic expressions in Hungarian.] In Tolcsvai Nagy Gábor and Szilárd Tátrai, eds. Konstrukció és jelentés, 231-257. [Construction and meaning.] Budapest: ELTE.

Langacker, Ronald W. (2008) Cognitive grammar: a basic introduction. Oxford: Oxford University Press.

Lyons, John (1977) Semantics. Cambridge: Cambridge University Press.

Sanders, José and Wilbert Spooren (1997) "Perspective, subjectivity, and modality from a cognitive point of view". In Wolf-Andreas Liebert, Gisela Redeker, and Linda Waugh, eds. Discourse and Perspective in Cognitive Linguistics, 85-112. Amsterdam, Philadelphia: John Benjamins.

Sinha, Chris (1999) "Grounding, mapping and acts of meaning". In Theo Janssen and Gisela Redeker, eds. Cognitive Linguistics: Foundations, Scope and Methodology, 223-255. Berlin and New York: Mouton de Gruyter.

Sinha, Chris (2005) "Biology, culture and the emergence and elaboration of symbolization". In Anjum P. Saleemi, Ocke-Schwen Bohn, and Albert Gjedde, eds. Search of a language for the mind-brain: can the multiple perspective unified?, 311-335. Aarhus: Aarhus University Press.

Tátrai, Szilárd (2008) "Perspective and deixis in narrative discourses". In Gábor Tolcsvai Nagy, ed. Function and genres, 257-270. (Metalinguistica, 20.) Frankfurt am Main: Peter Lang.

Tátrai, Szilárd (2011) Bevezetés a pragmatikába. Funkcionális kognitív megközelités. [Introduction to pragmatics: a functional cognitive approach.] Budapest: Tinta Könyvkiadó.

Tátrai, Szilárd and Nóra Csontos (2009) "Perspectivization and modes of quoting in Hungarian". Acta Linguistica Hungarica 56, 4, 441-468.

Tátrai, Szilárd (2015) "Context-dependent vantage points in literary narratives: a fuctional cognitive approach". Semiotica 203, 9-37.

Tomasello, Michael (1999) The cultural origins of human cognition. Cambridge MA: Harvard University Press.

Verhagen, Arie (2007) "Construal and perspectivization". In Dirk Geeraerts and Hubert Cuyckens, eds. The Oxford Handbook of cognitive linguistics, 48-81. Oxford: Oxford University Press.

Verschueren, Jef (1999) Understanding pragmatics. London, New York, Sydney, Auckland: Arnold. 


\begin{abstract}
Kokkuvõte. Krisztina Laczkó ja Szilárd Tátrai: Arvuti vahendatud narratiivide referentsiaalne tõlgendamine. Artikkel käsitleb narratiivide referentsiaalset tõlgendamist ühe arvuti vahendatud narratiividiskursuse näitel. Vaatluse all on ungarikeelsed jutustused interneti vestlusportaalis. Täpsemalt püütakse välja selgitada, mis suunab selliste jutustuste tõlgendamise käigus adressaadi tähelepanu ja kuidas. Lähtudes kognitiivse sotsiolingvistika vaatenurgast käsitletakse narratiivseid diskursusi ühise tähelepanu stseenidena, mille osalised panustavad referentsiaalsete (sh narratiivsete) stseenide intersubjektiivsesse tõlgendamisse üksteise tähelepanu suunates ja järgides. Uurimuse peamised tulemused on järgmised. 1) Jutustuste füüsilise ja sotsiaalse maailma tõlgendamisel mängib võtmerolli ruumilisel ja ajalisel lähedusel põhinev deiktiline suhe, mis ühendab jutustuse maailma narratiivi diskursuse maailmaga, mida tõlgendatakse ühise tähelepanu stseenina. 2) Need narratiivi diskursused objektiviseerivad sageli metapragmaatiliste meenutuste vormis nii referentsiaalse keskpunkti asukohta (mis paikneb jutustaja juures) kui ka jutustaja subjektiivset suhtumist jutustusse.
\end{abstract}

Märksõnad: ühise tähelepanu stseenid, narratiivid, kognitiivne sotsiolingvistika, deiksis, ungari keel 